\title{
P8-007
}

\section{精索の好酸球を伴う肉芽腫性血管炎に脊䯣炎を合併し, ステロイドが著効した一例}

\section{○福井翔一 ${ }^{1}$, 梅田雅孝 ${ }^{1}$, 西野文子 ${ }^{1}$, 中島好一 ${ }^{1}$, 古賀智裕 ${ }^{1}$, 川尻真也 ${ }^{1,2}$, 岩本直樹 ${ }^{1}$, 一瀬邦弘 ${ }^{1}$,} 平井康子 ${ }^{1}$, 玉井慎美 ${ }^{1}$, 中村英樹 ${ }^{1}$, 折口智樹 ${ }^{1,3}$, 川上 純 ${ }^{1}$ ( ${ }^{1}$ 長崎大学大学院医歯薬学総合研究科 展開医療科学講座 (第一内科), ${ }^{2}$ 長崎大学大学院医歯薬学総合 研究科社会医療科学講座 公衆衛生学分野, ${ }^{3}$ 長崎大学医学部 保健学科)

【症例】 70 歳男性【主訴】睪丸痛【現病歴】 30 年の糖尿病歴あり, 2 年前から糖尿病性腎症のため血液 透析中だった。X 年 8 月中旬に睪丸痛を自覚し, 発熱も伴っていたことから透析中の病院に入院し, 精巣炎・精巣上体炎の診断で抗生剂加療を行われるも改善しなかった. 8 月下旬より両下肢の筋力低下 のため, 歩行が徐々に困難となった。9月下旬より発熱が持続し, 睪丸痛も悪化し, 当院泌尿器科に緊 急搬送され，精巣上体炎の診断で緊急手術が行われた。手術後から末梢血の好酸球増多がみられ，病 理では精索間質の増生と好酸球浸潤とフィブリノイド壊死を伴う径 $0.5 \mathrm{~mm}$ までの小血管炎を認めたた め, 膠原病科に転科した。【入院後経過】抗好中球細胞質抗体（ANCA）は陰性で, 各種寄生虫抗体は 除性だった，両下肢の筋力低下がみられ，両側 Babinski 反射が陽性であり，MRIではC1 と Th4-6に $\mathrm{T} 2$ 強調画像で高信号域を灰白質主体に認めた。3 椎体にまたがる長大な病変だったが，視神経炎はみ られず，抗アクアポリン 4 抗体ならびに抗 Myelin oligodendrocyte glycoprotein (MOG) 抗体は陰性だっ た。髄液中の好酸球も陰性だった。病理所見から好酸球性多発血管炎性肉芽腫症と診断し, ステロイ ドパルスの後, プレドニン $50 \mathrm{mg}$ による後療法により好酸球は消失し筋力も回復した。 1 力月後の MRI では脊髄病変は著明に縮小していた。 